\title{
Modelling the behaviour state of humpback whales Megaptera novaeangliae in response to vessel presence off Sydney, Australia
}

\author{
Maryrose Gulesserian', ${ }^{1, *}$, David Slip ${ }^{1,2}$, Gillian Heller $^{3}$, Robert Harcourt $^{1}$ \\ ${ }^{1}$ Marine Mammal Research Group, Graduate School of the Environment, Macquarie University, Sydney, Australia 2109 \\ ${ }^{2}$ Taronga Conservation Society Australia, Sydney, Australia 2088 \\ ${ }^{3}$ Department of Statistics, Macquarie University, Sydney, Australia 2109
}

\begin{abstract}
The largest southern hemisphere humpback whale Megaptera novaeangliae stock (E1) uses the east coast of Australia as a migratory corridor to travel between their high-latitude feeding grounds in the Southern Ocean and low-latitude breeding grounds in northeast Queensland and the south-west Pacific Ocean. The population is recovering at close to the maximum rate of growth $\left(r_{\mathrm{m}}\right)$, and the increasing abundance of whales passing within sight of land has facilitated the development of a growing land- and vessel-based whale watching industry. We observed the behaviour of 156 individual pods of humpback whales passing Sydney, New South Wales, during their 2006 and 2007 northern migration and monitored vessel-whale interactions with respect to the Australian National Guidelines for Whale and Dolphin Watching 2005. We applied generalised linear mixed models with random effects to compute the odds of changing to the current behaviour state. We found that in the presence of vessels, whales were more likely to remain on the surface breathing or to cease surface breathing and switch to generally short, shallow diving than was the case when no vessels were present. Northerly migrating whales off Sydney were more likely to remain on the surface breathing in the presence of vessels, rather than taking some form of vertical avoidance (deep, long dives) as reported elsewhere. Given the high rate of population increase of stock E1 and the low level of behavioural changes seen, it appears that for this population at least, adult humpback whales migrating to their breeding grounds are relatively robust to disturbance by whale watching.
\end{abstract}

KEY WORDS: Humpback whale - Migration - Boat disturbance - Odds ratios - Behaviour · Whale watching

- Resale or republication not permitted without written consent of the publisher

\section{INTRODUCTION}

Commercial viewing of wildlife is rapidly becoming the predominant economic use of large wild animals in the natural environment (Newsome et al. 2005). In particular, charismatic animals such as whales, penguins, bears, whale sharks, apes and elephants have become the focal point of many viewing operations (Newsome et al. 2005). The concomitant proliferation of wildlife tourism has raised inquiry into how tar- geted animals respond to disturbances. Frequently documented responses include short-term changes in behaviour, such as increased vigilance, relocation, ceasing or otherwise changing behaviour states and flight initiation. These are shown across a range of taxa, including birds (e.g. Galicia \& Baldassarre 1997), reptiles (e.g. Kerr et al. 2004), amphibians (e.g. Rodríguez-Prieto \& Fernández-Juricic 2005) and a number of terrestrial and marine mammals (e.g. Chi \& Gilbert 1999, Cassini 2001, Pelletier 2006). 
Wildlife viewing has been marketed as non-consumptive, leading to the assumption that this form of tourism is somewhat benign, with no impact on the targeted animals (Jelinski et al. 2002), as well as carrying an implicit presumption of long-term sustainability. However, these assumptions may require careful evaluation, as for some animal species there may be causative links between tourism and disturbance (e.g. Holmes et al. 2005). While some animals become habituated to human activity (e.g. Coleman et al. 2008), others have remained wary and avoid areas of high levels of human activity (e.g. Dyke et al. 1986). Continually responding to disturbance may impact activity budgets and reduce the amount of time an animal spends foraging, resting, and for mammals, suckling young (e.g. Yalden \& Yalden 1990). Moreover, moving away from a disturbance may displace animals from preferred areas (e.g. Bryant et al. 1984).

The rapid growth of the whale watching industry has raised concerns about the potential impacts the industry may have on these animals, particularly because most activities take place in coastal areas and take advantage of seasonal or resident populations. Responses to disturbance have been reported in many cetacean species, including humpback whales Megaptera novaeangliae (e.g. Bauer et al. 1993), killer whales Orcinus orca (e.g. Bain et al. 2006, Williams \& Ashe 2007), bottlenose dolphins Tursiops spp. (e.g. Constantine et al. 2004, Lemon et al. 2006), fin whales Balaenoptera physalus (e.g. Stone et al. 1992), gray whales Eschrichtius robustus (e.g. Moore \& Clarke 2002), common dolphins Delphinus spp. (e.g. Stockin et al. 2008), dusky dolphins Lagenorhynchus obscurus (e.g. Barr \& Slooten 1999), Hector's dolphins Cephalorhynchns hectori (e.g. Bejder et al. 1999) and sperm whales Macrocephalus physeter (e.g. Richter et al. 2006).

Assessing the effects of whale watching activities on cetaceans is difficult, as changes in behaviour are expected to be subtle and difficult to detect because of the underwater nature of these species. Cetaceans may display a variety of short-term responses and strategies during vessel interactions, ranging from changes in pod composition (e.g. Ribeiro et al. 2005), movement patterns and habitat use (e.g. Bejder et al. 2006a, Lusseau 2006a,b), surfacing and dive times (e.g. Blane \& Jaakson 1994), activity and energy budgets (e.g. Williams et al. 2006), changes in swim speed (e.g. Jelinski et al. 2002) and changes in surface behaviour (e.g. Scheidat et al. 2004). While short-term changes in behaviour are relatively easy to identify, the biological significance of re- peated disturbances is more difficult to understand. Only a few studies have linked short-term changes to long-term effects, mainly in small cetaceans. For example, repeated disturbance has led to habitat abandonment (e.g. Bejder et al. 2006b), sensitisation (e.g. Constantine 2001) or reduced reproductive success (e.g. Bejder \& Samuels 2003) in some dolphin populations. However, while Watkins (1986) did find long-term changes in baleen whale behaviour in the face of repeated whale watching excursions over a 25 yr period, he concluded that for most species, the main effect was habituation, or even attraction in the case of humpback whales. While it is difficult to link disturbance to whales during migration to impacts at the population level, it is possible that excessive interference from vessels may have implications such as energetic costs, as whales adjust their behaviour.

One approach to evaluating the effects of vessel presence on cetaceans involves assessing sequences of behaviour states (Lusseau 2003). Because the observed behaviour state is influenced by the preceding state, behaviour sequence data can be particularly useful for modelling changes in these states due to external factors, such as vessel presence. Variations of this method have been demonstrated in a small number of studies on odontocetes, including bottlenose dolphins (Lusseau 2003), dusky dolphins (Dans et al. 2008), common dolphins (Stockin et al. 2008) and killer whales (Williams et al. 2006). Very few studies have previously documented sequential behaviour states of mysticetes (e.g. Schaffar et al. 2009).

Humpback whales are medium-sized mysticete whales with coastal migration in parts of their range. Humpback whales from the E1 (eastern Australia) breeding stock migrate up the east coast of Australia in the austral winter to breed before returning south to feed with newborn calves (Chittleborough 1965, Brown et al. 1995, Noad et al. 2010). This population was heavily decimated by coastal whaling in the 1950s, and the population collapsed by 1962 (Chittleborough 1965). Post-whaling surveys of the E1 population were initiated in Queensland in 1978, and the population is now recovering at close to the theoretical reproductive limit of the species, with an absolute abundance exceeding 14000 (Paterson et al. 1994, Noad et al. 2010). During their northward migration, the whales pass very close to shore off several major urban centres, from where many commercial whale watching vessels operate.

The fastest growth in whale watching in Australia has occurred in New South Wales (NSW), with an 
estimated average annual growth of $14.7 \%$ between 1998 and 2008 (O'Connor et al. 2009). Over the last decade, a significant whale watching industry has developed based out of Sydney, and in 2008 alone, over 25000 people boarded dedicated vessels in Sydney for the purpose of whale watching (IFAW 2004, O'Connor et al. 2009). To manage the rapidly growing industry, the Australian National Guidelines for Whale and Dolphin Watching 2005 were developed cooperatively by all Australian state and territory governments in order to form a basis by which states and territories could enact regulations nationwide providing for safe and sustainable cetacean watching in all Australian waters. NSW was the first state to implement these guidelines as state regulations (NSW National Parks and Wildlife Amendment [Marine Mammals] Regulation 2006). Although the guidelines provide defined approach speeds, distances and angles, they are not based on quantitative evidence. A greater understanding of the behavioural impacts of interactions between cetaceans and vessels is needed to assess the efficacy of the existing guidelines and to provide an empirical basis for these and any subsequent amendments.

In this paper, we assess whether the presence of vessels alters sequential changes in surface behaviour of migrating humpback whales on their northern migration to the breeding grounds.

\section{MATERIALS AND METHODS}

\section{Study site}

Data were collected from Cape Solander in Botany Bay National Park, Sydney, Australia $\left(34^{\circ} 01^{\prime} \mathrm{S}\right.$, $151^{\circ} 14^{\prime} \mathrm{E}_{\text {; Fig. }}$ 1). The site was chosen because of its elevation and unobstructed view of the study area. Cape Solander is located at the south of the entrance to Botany Bay and is a popular location for viewing humpback whales on their annual northern migration (Nicholls et al. 2000). Only the northern migration was monitored for the purpose of our study, as whales generally travel closer to shore than on the southern migration. Cape Solander is also a transit area for vessels entering and departing the bay, including cargo ships, oil-carrying tankers, commercial and recreational fishing vessels and tour boats. The $31 \mathrm{~m}$ height of the observation area allowed for relatively long-range viewing of whales and vessel activity in the area. Importantly, as the observations took place from land, we did not have to account for

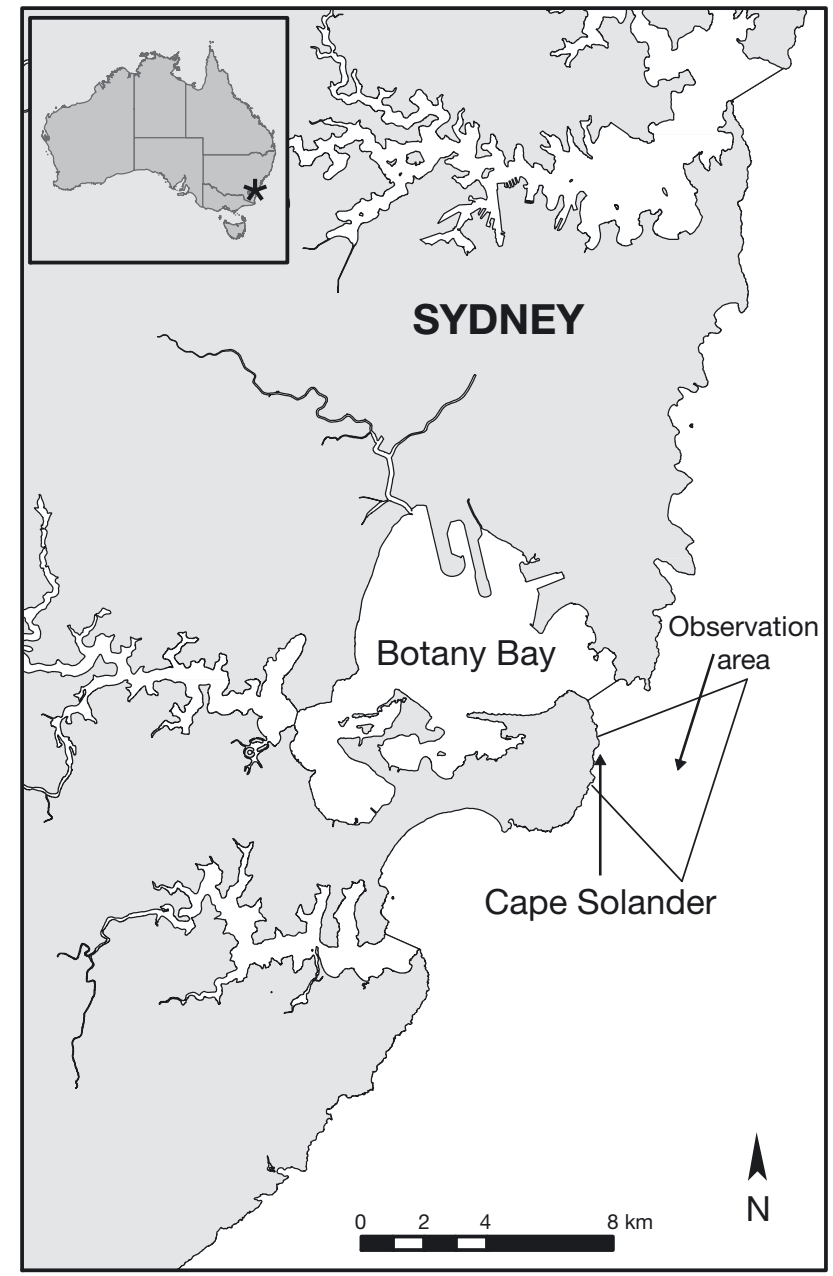

Fig. 1. Study area: Cape Solander, Sydney, Australia $\left(34^{\circ} 01^{\prime} \mathrm{S}, 151^{\circ} 14^{\prime} \mathrm{E}\right)$

a research boat effect on whale behaviour. Although longer-range viewing was possible, only whales and vessels within a $4 \mathrm{~km}$ radius of the land station were considered for this study in order to reduce measurement error.

\section{Data collection}

Data were collected between 16 June and 30 July 2006 and between 24 May and 31 July 2007, timed to coincide with the peak of the northern migration (Nicholls et al. 2000, Vang 2002). Observations were made using the naked eye and $7 \times 50$ magnitude binoculars. Data were recorded using a Sokkisha SET4A theodolite (with a precision of $\pm 5 \mathrm{~s}$ of arc, $30 \times$ magnification and set up at $1.473 \mathrm{~m}$ high), connected to a laptop computer running the custom 
written software Cyclops ${ }^{\circledR}$ (Version 3.16, E. Kneist, University of Newcastle). The theodolite simultaneously measured horizontal and vertical angles to a target (measured from a reference point of known latitude and longitude), which was plotted by Cyclops ${ }^{\circledR}$ in real time.

All vessel activity in the area was monitored and tracked using 15 min scan sampling (Martin \& Bateson 1998). While pods were being tracked, vessels were tracked opportunistically between every surfacing bout of the pod. Observations took place from dawn to dusk (subject to daylight, but generally 06:30 to 17:00 h) on a near daily basis, dependent on weather conditions. Observations were restricted to no rain, and Beaufort states $\leq 3$, as the ability to identify and monitor pods accurately decreased with rain and higher Beaufort states.

At least 2 people constantly scanned to the south for approaching pods. A pod was defined as either a lone whale or a group of whales with members of the group within $100 \mathrm{~m}$ of each other moving in the same direction (Corkeron 1995).

When a pod was seen, initial observations included identifying the number of animals in the pod and differentiating between individuals. Humpback whales generally travel in small groups; therefore, it is possible to distinguish individuals by the presence or absence of natural markings on their backs and the shape of their dorsal fins (Katona \& Whitehead 1981, Vang 2002). An individual animal was selected in the pod by means of natural markings and used for continuous focal-animal sampling throughout the observation period (Mann 1999). Every surfacing event was recorded for that individual, from the moment it came into view, until it left the study site, or until visibility was hindered. The distance to vessels within $1 \mathrm{~km}$ of each surfacing was also recorded. When a pod moved out of the study site, the next pod selected for tracking was the southernmost pod in the study area (if present).

No pods were observed swimming south during the monitoring period, and the main calving/breeding areas are more than $1000 \mathrm{~km}$ north of the study site. Thus, for the purpose of this study, every pod was assumed to be an independent observation.

\section{Data extraction and classification}

Only pods that were tracked for at least $15 \mathrm{~min}$ were included for analysis. Any moving vessel that came within $1000 \mathrm{~m}$ of a pod was considered to be within the 'interaction zone'.
Migrating humpback whales alternate series of short periods at the surface with longer submergences or dives (Chu 1988). In order to distinguish short submergences during a surfacing interval from longer dives, a log-survivorship curve of dive times was constructed to define the bout criterion interval (BCI; Martin \& Bateson 1998). The point of inflection determined the 'break point' of the ending of a surfacing event and the beginning of a dive (Martin \& Bateson 1998). Behaviour states were defined as long behaviours of measurable duration (in this case, the behaviours displayed at each surfacing event), as opposed to behaviour events which are brief, instantaneous behaviours, usually measured as a frequency (such as a breach or a tail slap; Altmann 1974, Mann 1999). For each surfacing period, the activity of the whale was assigned a behaviour state (Table 1), the preceding behaviour state and the presence or absence of a vessel within $1000 \mathrm{~m}$. The behaviour state categories summarised the behaviours displayed during the surfacing event.

\section{Data analysis}

Each surfacing event was recorded as an observation. Five binary variables were created, 1 for each of the behavioural states (blow only; blow and fluke up dive; blow and fluke down dive; surface active [no dive]; surface active [with dive]). If, for example, a whale was observed in the 'blow and fluke up dive' state, a '1' was recorded for that binary variable, and

Table 1. Megaptera novaeangliae. Five behaviour states of humpback whales from Cape Solander, New South Wales, designated for each surfacing period

$\begin{array}{ll}\begin{array}{l}\text { Behaviour state } \\ \text { Blow only }\end{array} & \begin{array}{l}\text { Description } \\ \text { Whale only surfaces to breathe, and }\end{array} \\ \begin{array}{l}\text { Blow and fluke } \\ \text { up dive }\end{array} & \begin{array}{l}\text { Surfacing period includes a 'fluke up } \\ \text { dive' (generally signifying a long, deep } \\ \text { dive) }\end{array} \\ \begin{array}{l}\text { Blow and fluke } \\ \text { down dive }\end{array} & \begin{array}{l}\text { Surfacing period includes a 'fluke } \\ \text { down dive' (generally signifying a } \\ \text { short, shallow dive) }\end{array} \\ \begin{array}{l}\text { Surface active } \\ \text { (no dive) }\end{array} & \begin{array}{l}\text { Active at the surface and does not dive } \\ \text { Surface activity includes tail slap, } \\ \text { peduncle slap, pectoral slap, head slap } \\ \text { or any other activity at the surface }\end{array} \\ \begin{array}{l}\text { Active at the surface and includes a } \\ \text { (with dive) }\end{array} & \begin{array}{l}\text { dive as part of the surfacing period } \\ \text { dive }\end{array}\end{array}$


0s for the other 4 binary behavioural state variables. Five logistic regression models were constructed, 1 for each behavioural state, and a random effect was used to model within-pod clustering (the tendency for whales within a pod to behave more similarly to each other than whales in different pods), within the framework of generalised linear mixed models (Zar 1999). Serial correlation between successive observations was accounted for by including the previous behavioural state as a covariate. The presence of vessels within $1000 \mathrm{~m}$ and the interaction of preceding behaviour state with vessel presence were the other covariates.

For all statistical analyses, a 5\% significance level was used. A significant vessel presence-behavioural state interaction term indicated that the odds of changing from the previous to the current behaviour state depended on the presence of a vessel. We use the term 'odds' following Zar (1999), where 'odds' is the ratio of the probability of an event occurring versus it not occurring, rather than the term 'probability', which is the relative frequency. All statistical analyses were performed using $\mathrm{R}$ (Version 2.9.1; R Development Core Team 2009) with the package 'lme4' (Bates \& Maechler 2009).

Lusseau (2003) used Markov chain methods for modelling changes in behaviour states. The 'mixed model' logistic regression approach which we have adopted is a valid alternative to this approach. It allows the estimation of all of the parameters that we need to evaluate changes in whale behaviour, while also incorporating within-pod clustering and serial correlation between successive states.

\section{RESULTS}

A total of 936 dives by 156 individual pods of humpback whales were plotted to obtain an inflection point of $1.2 \mathrm{~min}$. Therefore, every surfacing period with a downtime of less than 1.2 min was assigned a unique 'surfacing' number. Any downtime longer than 1.2 min was considered a dive, and the following surfacing was given the next consecutive number. The frequency of behaviours observed in the presence and absence of vessels is presented in Table 2. The mean duration of tracking sessions per pod was $34.68 \pm 14.16 \mathrm{~min}$ (range: 15 to $82 \mathrm{~min}$ ). The median pod size was 2 whales, with pods ranging from 1 to 6 whales.

Results of the logistic regressions for the 5 behaviour states are shown in Tables 3-7, respectively. The presence of a vessel significantly increased the odds of changing to a 'blow only' state, when the preceding behaviour states were 'blow and fluke up dive' $(\mathrm{p}=0.006)$ or 'surface active with dive' $(\mathrm{p}=$ 0.031), i.e. whales ceased undertaking deep dives and curtailed activity at the surface, switching instead to remaining at the surface and taking breaths (Table 3, Fig. 2).

In addition, the presence of a vessel significantly increased the odds of changing to a 'blow and fluke down dive' state when the preceding behaviour state was 'blow only' (Table 5; p = 0.028), i.e. whales switched from remaining at the surface to taking shallow dives (Fig. 3).

The odds of changing to a behavioural state are computed as a product of the appropriate odds ratios as given in Tables 3-7. For example, the odds of changing to 'blow only', with vessels present and preceding behaviour state 'blow and fluke up dive', is $1.368 \times 0.388 \times 0.246 \times 2.858=$ 0.373 . This corresponds to a probability of $0.373 /$ $(1+0.373)=0.272$.

Table 2. Megaptera novaeangliae. Frequency of behaviours observed in the presence and absence of vessels

\begin{tabular}{|lrc|}
\hline Behaviour state & Vessels absent & Vessels present \\
\hline Blow only & 277 & 101 \\
Blow and fluke up dive & 229 & 147 \\
Blow and fluke down dive & 68 & 29 \\
Surface active (no dive) & 52 & 28 \\
Surface active (with dive) & 24 & 19 \\
\hline
\end{tabular}

Table 3. Megaptera novaeangliae. Logistic regression results for behavioural state 'blow only'

\begin{tabular}{|c|c|c|c|c|}
\hline & $\begin{array}{l}\text { Coeffi- } \\
\text { cient }\end{array}$ & $\mathrm{SE}$ & $\begin{array}{l}\text { Odds } \\
\text { ratio }\end{array}$ & $\mathrm{p}$ \\
\hline Intercept & 0.313 & 0.158 & 1.368 & 0.048 \\
\hline Vessel presence & -0.946 & 0.266 & 0.388 & $<0.001$ \\
\hline \multicolumn{5}{|l|}{ Previous state } \\
\hline Blow and fluke up dive & -1.404 & 0.228 & 0.246 & $<0.001$ \\
\hline Blow and fluke down dive & -1.219 & 0.358 & 0.296 & 0.001 \\
\hline Surface active (no dive) & -0.968 & 0.341 & 0.380 & 0.005 \\
\hline Surface active (with dive) & -2.201 & 0.688 & 0.111 & 0.001 \\
\hline \multicolumn{5}{|c|}{ Vessel presence $\times$ Previous state } \\
\hline $\begin{array}{l}\text { Vessel presence } \times \text { Blow } \\
\text { and fluke up dive }\end{array}$ & 1.05 & 0.381 & 2.858 & 0.006 \\
\hline $\begin{array}{l}\text { Vessel presence } \times \text { Blow } \\
\text { and fluke down dive }\end{array}$ & 0.904 & 0.584 & 2.469 & 0.122 \\
\hline $\begin{array}{l}\text { Vessel presence } \times \text { Surface } \\
\text { active (no dive) }\end{array}$ & 0.02 & 0.723 & 1.020 & 0.978 \\
\hline $\begin{array}{l}\text { Vessel presence } \times \text { Surface } \\
\text { active (with dive) }\end{array}$ & 1.93 & 0.893 & 6.890 & 0.031 \\
\hline
\end{tabular}


Table 4. Megaptera novaeangliae. Logistic regression results for behavioural state 'blow and fluke up dive'

\begin{tabular}{|c|c|c|c|c|}
\hline & $\begin{array}{l}\text { Coeffi- } \\
\text { cient }\end{array}$ & $\mathrm{SE}$ & $\begin{array}{l}\text { Odds } \\
\text { ratio }\end{array}$ & $\mathrm{p}$ \\
\hline Intercept & 0.325 & 0.181 & 1.384 & 0.073 \\
\hline Vessel presence & -0.5 & 0.27 & 0.607 & 0.064 \\
\hline \multicolumn{5}{|l|}{ Previous state } \\
\hline Blow only & -1.562 & 0.236 & 0.210 & $<0.001$ \\
\hline $\begin{array}{l}\text { Blow and fluke down } \\
\text { dive }\end{array}$ & -2.064 & 0.441 & 0.127 & $<0.001$ \\
\hline Surface active (no dive) & -2.077 & 0.485 & 0.125 & $<0.001$ \\
\hline $\begin{array}{l}\text { Surface active (with } \\
\text { dive) }\end{array}$ & -0.801 & 0.489 & 0.449 & 0.101 \\
\hline \multicolumn{5}{|c|}{ Vessel presence $\times$ Previous state } \\
\hline $\begin{array}{l}\text { Vessel presence } \times \\
\text { Blow only }\end{array}$ & 1.553 & 0.38 & 4.726 & $<0.001$ \\
\hline $\begin{array}{l}\text { Vessel presence } \times \text { Blow } \\
\text { and fluke down dive }\end{array}$ & 1.881 & 0.624 & 6.560 & 0.003 \\
\hline $\begin{array}{l}\text { Vessel presence } \times \text { Surface } \\
\text { active (no dive) }\end{array}$ & 0.02 & 0.975 & 1.020 & 0.984 \\
\hline $\begin{array}{l}\text { Vessel presence } \times \text { Surface } \\
\text { active (with dive) }\end{array}$ & 0.388 & 0.742 & 1.474 & 0.601 \\
\hline
\end{tabular}

Table 5. Megaptera novaeangliae. Logistic regression results for behavioural state 'blow and fluke down dive'

\begin{tabular}{|lcccc|}
\hline & $\begin{array}{c}\text { Coeffi- } \\
\text { cient }\end{array}$ & SE & $\begin{array}{c}\text { Odds } \\
\text { ratio }\end{array}$ & $\mathrm{p}$ \\
\hline Intercept & 0.208 & 0.264 & 1.231 & 0.432 \\
Vessel presence & -1.163 & 0.456 & 0.313 & 0.011 \\
Previous state & & & & \\
Blow only & -2.792 & 0.351 & 0.061 & $<0.001$ \\
Blow and fluke up dive & -2.758 & 0.37 & 0.063 & $<0.001$ \\
Surface active (no dive) & -18.774 & 1376.9 & 0.000 & 0.989 \\
Surface active (with dive) & -18.774 & 2109 & 0.000 & 0.993 \\
Vessel presence $\times$ Previous state & & & \\
Vessel presence $\times$ & 1.359 & 0.619 & 3.892 & 0.028 \\
$\begin{array}{l}\text { Blow only } \\
\text { Vessel presence } \times \text { Blow }\end{array}$ & 0.933 & 0.639 & 2.542 & 0.144 \\
$\quad$ and fluke up dive & 1.163 & 2674.5 & 3.200 & 0.999 \\
$\begin{array}{l}\text { Vessel presence } \times \\
\text { Surface active (no dive) }\end{array}$ & 17.478 & 2109 & $3.9 \times 10^{7}$ & 0.993 \\
$\begin{array}{l}\text { Vessel presence } \times \\
\text { Surface active (with dive) }\end{array}$ & & & & \\
\hline
\end{tabular}

\section{DISCUSSION}

The analysis of behavioural sequences is a powerful method of examining individual changes in behaviour and provides insights into whether preceding behaviour states had consequences in the face of change. We have shown that it is possible to robustly apply generalised linear mixed models with random effects to compute the odds of whales'
Table 6. Megaptera novaeangliae. Logistic regression results for behavioural state 'surface active (no dive)'

\begin{tabular}{|c|c|c|c|c|}
\hline & $\begin{array}{l}\text { Coeffi- } \\
\text { cient }\end{array}$ & SE & $\begin{array}{l}\text { Odds } \\
\text { ratio }\end{array}$ & $\mathrm{p}$ \\
\hline Intercept & -1.542 & 0.349 & 0.214 & $<0.001$ \\
\hline Vessel presence & 0.932 & 0.591 & 2.540 & 0.115 \\
\hline \multicolumn{5}{|l|}{ Previous state } \\
\hline Blow only & -1.728 & 0.427 & 0.178 & $<0.001$ \\
\hline Blow and fluke up dive & -3.211 & 0.769 & 0.040 & $<0.001$ \\
\hline $\begin{array}{l}\text { Blow and fluke down } \\
\text { dive }\end{array}$ & -18.336 & 2838.2 & 0.000 & 0.995 \\
\hline Surface active (with dive) & -0.606 & 0.655 & 0.546 & 0.355 \\
\hline \multicolumn{5}{|c|}{ Vessel presence $\times$ Previous state } \\
\hline $\begin{array}{l}\text { Vessel presence } \times \\
\text { Blow only }\end{array}$ & -0.906 & 0.817 & 0.404 & 0.267 \\
\hline $\begin{array}{l}\text { Vessel presence } \times \text { Blow } \\
\text { and fluke up dive }\end{array}$ & 0.501 & 1.03 & 1.650 & 0.626 \\
\hline $\begin{array}{l}\text { Vessel presence } \times \text { Blow } \\
\text { and fluke down dive }\end{array}$ & -0.413 & 3978.1 & 0.662 & 1 \\
\hline $\begin{array}{l}\text { Vessel presence } \times \\
\text { Surface active (with dive) }\end{array}$ & -0.697 & 1.025 & 0.498 & 0.496 \\
\hline
\end{tabular}

Table 7. Megaptera novaeangliae. Logistic regression results for behavioural state 'surface active (with dive)'

\begin{tabular}{|c|c|c|c|c|}
\hline & $\begin{array}{l}\text { Coeffi- } \\
\text { cient }\end{array}$ & $\mathrm{SE}$ & $\begin{array}{l}\text { Odds } \\
\text { ratio }\end{array}$ & $\mathrm{p}$ \\
\hline Intercept & -2.195 & 0.54 & 0.111 & $<0.001$ \\
\hline Vessel presence & -1.428 & 1.008 & 0.240 & 0.157 \\
\hline \multicolumn{5}{|l|}{ Previous state } \\
\hline Blow only & -2.607 & 0.815 & 0.074 & $<0.001$ \\
\hline Blow and fluke up dive & -2.447 & 0.799 & 0.087 & 0.002 \\
\hline $\begin{array}{l}\text { Blow and fluke down } \\
\text { dive }\end{array}$ & -2.243 & 1.405 & 0.106 & 0.11 \\
\hline Surface active (no dive) & -0.581 & 0.68 & 0.559 & 0.393 \\
\hline \multicolumn{5}{|c|}{ Vessel presence $\times$ Previous state } \\
\hline $\begin{array}{l}\text { Vessel presence } \times \text { Blow } \\
\text { only }\end{array}$ & 1.687 & 1.468 & 5.403 & 0.251 \\
\hline $\begin{array}{l}\text { Vessel presence } \times \text { Blow } \\
\text { and fluke up dive }\end{array}$ & 2.774 & 1.241 & 16.023 & 0.025 \\
\hline $\begin{array}{l}\text { Vessel presence } \times \text { Blow } \\
\text { and fluke down dive }\end{array}$ & 3.038 & 1.801 & 20.863 & 0.092 \\
\hline $\begin{array}{l}\text { Vessel presence } \times \text { Surface } \\
\text { active (no dive) }\end{array}$ & 1.815 & 1.242 & 6.141 & 0.144 \\
\hline
\end{tabular}

behaviour changing to the current behaviour state as a function of the interaction between the preceding behaviour state and the presence of vessels.

We found that whales were more likely to curtail deep diving and activity at the surface and instead to remain on the surface breathing when vessels were within $1000 \mathrm{~m}$. This is similar to behaviour seen by Watkins (1986) when whale watching boats approached humpback whales off Cape Cod, USA. 


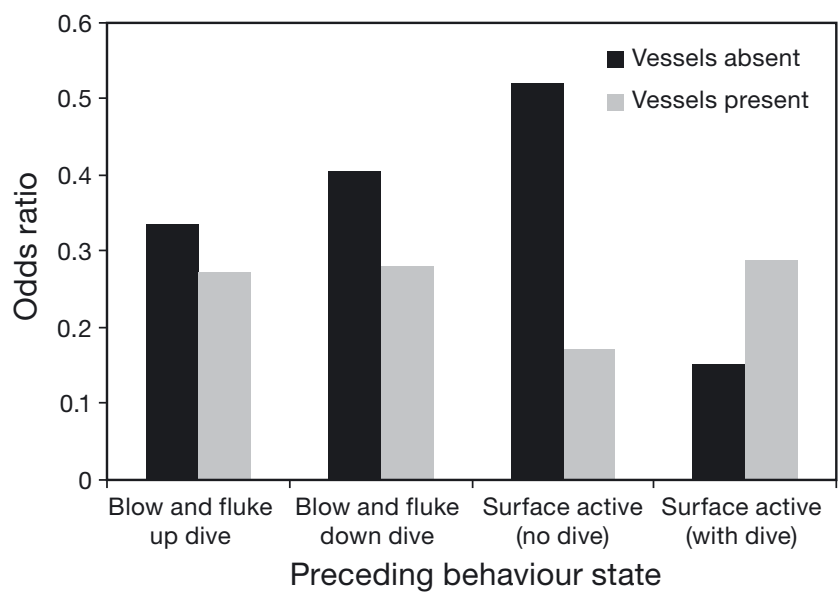

Fig. 2. Megaptera novaeangliae. Odds of changing to behavioural state 'blow only' as a factor of the preceding behaviour state and vessel presence

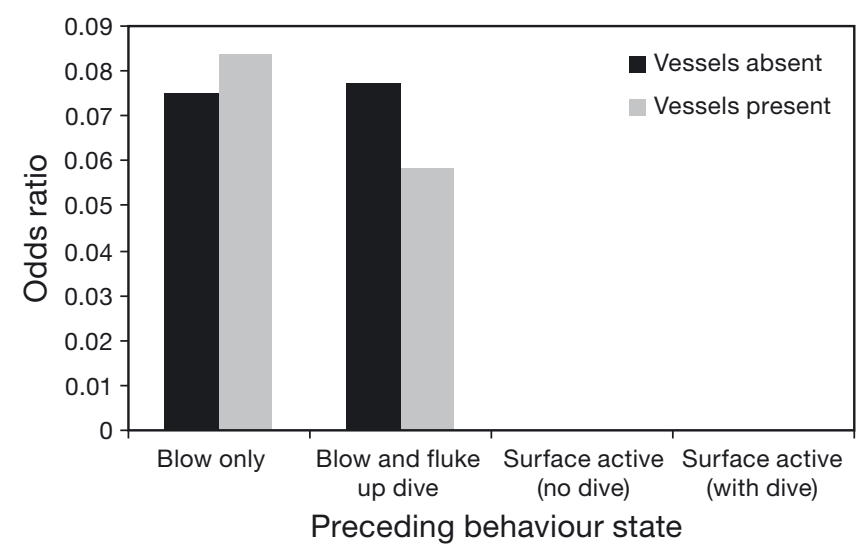

Fig. 3. Megaptera novaeangliae. Odds of changing to behavioural state 'blow and fluke down dive' as a factor of the preceding behaviour state and vessel presence. Odds were zero for 'surface active'

Further, whales were more likely to cease surface breathing and switch to generally short, shallow diving ('fluke down dive'). The present study indicates that northerly migrating whales off Sydney are more likely to remain on the surface breathing in the presence of vessels than they are to take some form of vertical avoidance (deep, long dives). In contrast, Stamation et al. (2010) found that southerly migrating whales from the same population but further south, in an area where feeding occurs, showed longer submergences in the presence of vessels. Similarly, 2 decades ago, travelling humpback whales on their southern migration but further north, in a resting area off Hervey Bay, were more likely to dive than to slip underwater in the presence of vessels (Corkeron 1995). In the same study, pods with calves that never dived in the absence of vessels did so when vessels were present, as well as ending activity at the surface (Corkeron 1995). Given the changes in humpback whale behaviour from avoidance to positive interactions reported by Watkins (1986) over a similar time span, behaviour responses of humpback whales in Hervey Bay need revisiting. Cessation of surface activity has also been recorded in Hawaii, USA, where humpback whales decreased surface activity when vessels came within $~ 800 \mathrm{~m}$ (Green \& Green 1990). The significance of increased surface activity is unknown, but the migratory corridor off Sydney during the northerly migration is relatively narrow (Nicholls et al. 2000, Vang 2002). It is possible that the differences in the northward and southward migration may be due to the oceanographic or topographic conditions. The southern migration tends to be further offshore, in deeper water and with the benefit of the Eastern Australian Current. It may be that during the northern migration, whales are constrained by shallower water and the boundary of the southerly flowing current, which may preclude a deep diving 'escape' response and favour a surface 'vigilance' response.

That these whales consistently spent more time at the surface in the presence of vessels and did not respond by diving and swimming away, suggests that vessels did not in general invoke a flight response. Rather, animals became relatively quiet in response to vessel presence. It appears that at least for northerly migrating adult humpback whales, the current Australian national guidelines ('National Guidelines for Whale and Dolphin Watching 2005') and state regulations are probably appropriate in terms of minimising disturbance. However, the reports by Stamation et al. (2010) and Corkeron (1995) are of different, highly variable responses by whales on their southern migration in resting or feeding areas or accompanied by calves, suggesting that caution must be used in generalising across different life stages and/or time periods.

The effects reported in this study were a function of vessel presence, regardless of vessel type. We refer to the national guidelines and state regulations, as they are applicable to all recreational and commercial vessels.

One of the challenges in studying animal behaviour is to take into account individual variation when making general conclusions. The method used in this study addressed individual variation by including individuals as a random effect. Measures of variance were universally low, indicating little individual vari- 
ation in migratory humpback whale responses. This is in stark contrast to the cross-sectional reports of differences by Stamation et al. (2010). The responses reported in our study therefore appear broadly applicable to adult humpback whales on their northerly migration at this particular location.

We detected consistent, low-level changes in behaviour states. This does not necessarily indicate longterm detrimental effects. Every new behavioural occurrence need not be automatically interpreted as a response to deleterious human pressures (Wolfson 1977). Many of the locations where whale watching is intense and has occurred for decades have seen a concurrent increase in whale numbers (i.e. humpback whales in Maui and gray whales off the west coast of North America; e.g. Calambokidis et al. 2008, Punt \& Wade 2010) and amelioration of responses (Watkins 1986). Thus, the contention of some studies that suggest behavioural change induced by whale watching activities invariably reflect negative impacts for whales is not borne out by constraints on population recovery. Behaviour is likely to be influenced by internal motivational factors, as well as external factors, such as environmental parameters and disturbances (Slooten 1994). Given that the estimated rate of increase in the E1 breeding stock is $10.9 \% \mathrm{yr}^{-1}$ (95\% CI: $10.5-11.3 \%$ ), which is close to a theoretical estimate of the maximum rate of growth $\left(r_{\mathrm{m}}\right)$, and that this is a long-term trend over at least the last 26 yr (Noad et al. 2010), it appears that for this population at least, adult humpback whales migrating to their breeding grounds may be relatively robust to disturbance by whale watching.

Acknowledgements. This project was funded by ARC Linkage grant LP0776840, with additional support from the NSW Department of Environment and Climate Change and Bass \& Flinders cruises. We thank E. Kneist (author of Cyclops), G. Ross, W. Reynolds and the Cape Solander Migration Study for facilitating the research, and members of the Marine Mammal Research Group, particularly F. Viddi, as well as 3 anonymous reviewers for helpful discussions.

\section{LITERATURE CITED}

Altmann J (1974) Observational study of behavior: sampling methods. Behaviour 49:227-267

Bain DE, Williams R, Smith JC, Lusseau D (2006) Effects of vessels on behavior of southern resident killer whales (Orcinus spp.) 2003-2005. NMFS Contract Nos. AB133 F03SE0959 and AB133F04CN0040 available at www. nwfsc.noaa.gov/research/divisions/cbd/marine_mammal/ documents/bainnmfsrep2003-5final.pdf
Barr K, Slooten E (1999) Effects of tourism on dusky dolphins at Kaikoura. Conservation Advisory Science Notes No. 229, Department of Conservation, Wellington

Bates D, Maechler M (2009) lme4: linear mixed-effects models using s4 classes. R package version 0.999375-31. Available at http://CRAN.R-project.org/package=lme4

> Bauer GB, Mobley JR, Herman LM (1993) Responses of wintering humpback whales to vessel traffic. J Acoust Soc Am 94:1848

Bejder L, Samuels A (2003) Evaluating the effects of naturebased tourism on cetaceans. In: Gales N, Hindell M, Kirkwood R (eds) Marine mammals: fisheries, tourism and management issues. CSIRO Publishing, Collingwood, p 229-256

> Bejder L, Dawson SM, Harraway JA (1999) Responses by Hector's dolphins to boats and swimmers in Porpoise Bay, New Zealand. Mar Mamm Sci 15:738-750

Bejder L, Samuels A, Whitehead H, Gales N (2006a) Interpreting short-term behavioural responses to disturbance within a longitudinal perspective. Anim Behav 72: 1149-1158

Bejder L, Samuels A, Whitehead H, Gales N and others (2006b) Decline in relative abundance of bottlenose dolphins exposed to long-term disturbance. Conserv Biol 20:1791-1798

Blane JM, Jaakson R (1994) The impact of ecotourism boats on the St. Lawrence beluga whales. Environ Conserv 21:267-269

Brown MR, Corkeron PJ, Hale PT, Schultz KW, Bryden MM (1995) Evidence for a sex-segregated migration in the humpback whale (Megaptera novaeangliae). Proc Biol Sci 259:229-234

Bryant PJ, Lafferty CM, Lafferty SK (1984) Reoccupation of Laguna Guerrero Negro, Baja California, Mexico, by gray whales. In: Jones ML, Swartz SL, Leatherwood S (eds) The gray whale Eschrichtius robustus. Academic Press, Orlando, FL, p 375-388

Calambokidis J, Falcone EA, Quinn TJ, Burdin AM and others (2008) SPLASH: structure of populations, levels of abundance and status of humpback whales in the North Pacific. Final report for contract AB133F-03-RP-00078. Cascadia Research, Olympia, WA

> Cassini MH (2001) Behavioural responses of South American fur seals to approach by tourists - a brief report. Appl Anim Behav Sci 71:341-346

Chi DK, Gilbert BK (1999) Habitat security for Alaskan black bears at key foraging sites: Are there thresholds for human disturbance? Ursus 11:225-237

Chittleborough RG (1965) Dynamics of two populations of the humpback whale, Megaptera novaeangliae (Borowski). Aust J Mar Freshw Res 16:33-128

Chu KC (1988) Dive times and ventilation patterns of singing humpback whales (Megaptera novaeangliae). Can J Zool 66:1322-1327

> Coleman A, Richardson D, Schechter R, Blumstein DT (2008) Does habituation to humans influence predator discrimination in Gunther's dik-diks (Madoqua guentheri)? Biol Lett 4:250-252

Constantine R (2001) Increased avoidance of swimmers by wild bottlenose dolphins (Tursiops truncatus) due to long-term exposure to swim-with-dolphin tourism. Mar Mamm Sci 17:689-702

> Constantine R, Brunton DH, Dennis T (2004) Dolphinwatching tour boats change bottlenose dolphin (Tursiops truncatus) behaviour. Biol Conserv 117:299-307 
Corkeron PJ (1995) Humpback whales (Megaptera novaeangliae) in Hervey Bay, Queensland: behaviour and responses to whale-watching vessels. Can J Zool 73: 1290-1299

Dans SL, Crespo EA, Pedraza SN, Degrati M, Garaffo GV (2008) Dusky dolphin and tourist interaction: effect on diurnal feeding behavior. Mar Ecol Prog Ser 369: 287-296

> Dyke FGV, Brocke RH, Shaw HG, Ackerman BB, Hemker TP, Lindzey FG (1986) Reactions of mountain lions to logging and human activity. J Wildl Manag 50:95-102

Galicia E, Baldassarre GA (1997) Effects of motorized tourboats on the behavior of nonbreeding American flamingos in Yucatan, Mexico. Conserv Biol 11:1159-1165

Green M, Green RG (1990) Short-term impacts of vessel traffic on the Hawaiian humpback whale (Megaptera novaeangliae). Paper presented at the Annual Meeting of the Animal Behaviour Society, Buffalo, NY, June 1990. Available at: www.oceanmammalinst.com/w90.html

> Holmes N, Giese M, Kriwoken LK (2005) Testing the minimum approach distance guidelines for incubating royal penguins Eudyptes schlegeli. Biol Conserv 126:339-350

IFAW (International Fund for Animal Welfare) (2004) The growth of whale watching tourism in Australia: an International Fund for Animal Welfare report. IFAW Asia Pacific, Surry Hills

$>$ Jelinski DE, Krueger CC, Duffus DA (2002) Geostatistical analyses of interactions between killer whales (Orcinus orca) and recreational whale-watching boats. Appl Geogr 22:393-411

Katona SK, Whitehead HP (1981) Identifying humpback whales using their natural markings. Polar Rec 20: 439-444

Kerr GD, Bull CM, Mackay D (2004) Human disturbance and stride frequency in the sleepy lizard (Tiliqua rugosa): implications for behavioral studies. J Herpetol 38: 519-526

> Lemon M, Lynch TP, Cato DH, Harcourt RG (2006) Response of travelling bottlenose dolphins (Tursiops aduncus) to experimental approaches by a powerboat in Jervis Bay, New South Wales, Australia. Biol Conserv 127:363-372

> Lusseau D (2003) Effects of tour boats on the behavior of bottlenose dolphins: using Markov chains to model anthropogenic impacts. Conserv Biol 17:1785-1793

> Lusseau D (2006a) The short-term behavioral reactions of bottlenose dolphins to interactions with boats in Doubtful Sound, New Zealand. Mar Mamm Sci 22:802-818

Lusseau D (2006b) Why do dolphins jump? Interpreting the behavioural repertoire of bottlenose dolphins (Tursiops sp.) in Doubtful Sound, New Zealand. Behav Process 73:257-265

> Mann J (1999) Behavioral sampling methods for cetaceans: a review and critique. Mar Mamm Sci 15:102-122

Martin P, Bateson P (1998) Measuring behaviour: an introductory guide, 2nd edn. Cambridge University Press, Cambridge

Moore S, Clarke JT (2002) Potential impact of offshore human activities on gray whales (Eschrichtius robustus). J Cetacean Res Manag 4:19-25

Newsome D, Dowling R, Moore S (2005) Wildlilfe tourism. Channel View Publications, Clevedon

Nicholls AO, Shaughnessy PD, Ross GA, Reynolds WG, Briggs SV (2000) Analysis of counts of humpback whales (Megaptera novaeangliae) from Cape Solander, New
South Wales. Report to the New South Wales National Parks and Wildlife Service. CSIRO Wildlife and Ecology, Canberra

Noad MJ, Dunlop RA, Paton D, Kneist H (2010) Abundance estimates of the east Australian humpback whale population: 2010 survey and update. Paper presented to the IWC Scientific Committee, SC/63/SH22, June 2010. Available at http://iwcoffice.org/_documents/sci_com/ SC63docs/SC-63-SH22.pdf

O'Connor S, Campbell R, Cortez H, Knowles T (2009) Whale watching worldwide: tourism numbers, expenditures and expanding economic benefits, a special report from the International Fund for Animal Welfare, Yarmouth, MA

Paterson R, Paterson P, Cato DH (1994) The status of humpback whales Megaptera novaeangliae in east Australia thirty years after whaling. Biol Conserv 70:135-142

Pelletier F (2006) Effects of tourist activities on ungulate behaviour in a mountain protected area. J Mt Ecol 8: 15-19

Punt AE, Wade PR (2010) Population status of the eastern North Pacific stock of gray whales in 2009. NOAA Tech Memo NMFS-AFSC-207. US Department of Commerce, Springfield, VA

R Development Core Team (2009) R: a language and environment for statistical computing. R Foundation for Statistical Computing, Vienna. Available at: www. R-project.org

Ribeiro S, Viddi FA, Freitas TRO (2005) Behavioural responses of Chilean dolphins (Cephalorhynchus eutropia) to boats in Yaldad Bay, southern Chile. Aquat Mamm 31:234-242

> Richter C, Dawson S, Slooten E (2006) Impacts of commercial whale watching on male sperm whales at Kaikoura, New Zealand. Mar Mamm Sci 22:46-63

> Rodríguez-Prieto I, Fernández-Juricic E (2005) Effects of direct human disturbance on the endemic Iberian frog, Rana iberica, at individual and population levels. Biol Conserv 123:1-9

Schaffar A, Madon B, Garrigue C, Constantine R (2009) Avoidance of whale watching boats by humpback whales in their main breeding ground in New Caledonia. Paper presented to the IWC Scientific Committee, SC/ 61/WW6, June 2009. Available at http://iwcoffice.org/ _documents/sci_com/sc61docs/SC-61-WW6.pdf

Scheidat M, Castro C, Gonzalez J, Williams R (2004) Behavioural responses of humpback whales (Megaptera novaeangliae) to whalewatching boats near Isla de la Plata, Machalilla National Park, Ecuador. J Cetacean Res Manag 6:63-68

> Slooten E (1994) Behavior of Hector's dolphin: classifying behavior by sequence analysis. J Mammal 75:956-964

> Stamation K, Croft D, Shaughnessy P, Waples KA, Briggs S (2010) Behavioral responses of humpback whales (Megaptera novaeangliae) to whale-watching vessels on the southeastern coast of Australia. Mar Mamm Sci 26: 98-122

Stockin KA, Lusseau D, Binedell V, Wiseman N, Orams MB (2008) Tourism affects the behavioural budget of the common dolphin Delphinus sp. in the Hauraki Gulf, New Zealand. Mar Ecol Prog Ser 355:287-295

Stone SS, Katona SK, Mainwaring A, Allen JM, Corbett HD (1992) Respiration and surfacing rates of fin whales (Balaenoptera physalus) observed from a lighthouse tower. Rep Int Whal Comm 42:739-745 
Vang L (2002) Distribution, abundance and biology of group V humpback whales Megaptera novaeangliae: a review. Queensland Parks and Wildlife Service Environmental Protection Agency, Queensland

Watkins WA (1986) Whale reactions to human activities in Cape Cod waters. Mar Mamm Sci 2:251-262

Williams R, Ashe E (2007) Killer whale evasive tactics vary with boat number. J Zool (Lond) 272:390-397

Williams R, Lusseau D, Hammond PS (2006) Estimating rel-

Editorial responsibility: Clive McMahon,

Darwin, Australia ative energetic costs of human disturbance to killer whales (Orcinus orca). Biol Conserv 133:301-311

Wolfson FH (1977) Gray whale behavior. Science 195: 534-535

Yalden PE, Yalden DW (1990) Recreational disturbances of breeding golden plovers Pluvialis apricarius. Biol Conserv 51:243-262

Zar JH (1999) Biostatistical analysis. Prentice Hall, Upper Saddle River, NJ

Submitted: March 10, 2011; Accepted: August 22, 2011

Proofs received from author(s): November 11, 2011 